\title{
ALTERATIONS IN BIOCHEMICAL MARKERS OF COVID-19 AND USING IT AS DIAGNOSTIC AND PROGNOSTIC TOOLS
}

\author{
Athraa Sami \\ Department of Clinical Laboratory Science, Faculty of Pharmacy, University of Kufa, Alnajaf Al-Ashraf, \\ Iraq
}

*Corresponding author: athraas.alshebani@uokufa.edu.iq

\begin{abstract}
Biochemical markers (BM) play an important role in the early identification of COVID-19 and monitoring of infected people in order to evaluate the severity of infection and providing the proper care and optimum management to decrease mortality rate and disease progression. Prognostic tools are consider the essential approaches for making a decision in patient management and treatment for patients with COVID-19 infection. In this review, we determine the most important biomarkers of immunity, coagulation, cardiac and renal dysfunction as a highly valuable laboratory tools for diagnostic, monitoring, predicting the progressive complications of coronavirus infectious disease in order to give the effective treatment and for more efficiently control the pandemic.
\end{abstract}

Keywords: Biochemical markers, COVID-19, disease progression, renal dysfunction. 


\section{Introduction}

The rapid spread of the COVID-19 pandemic worldwide has prompted the health science community to investigate the appropriate, fast and accurate diagnostic and prognostic tools (Bano et al., 2020). These tools will assist risk classification, guide interventional reports to target infected patients at increased risk of development severe infection and identify allocation of limited technical and human resources in the current outbreak (Henry et al., 2020).

Moreover, laboratory biomarker is one of the most critical factor in prediction of progression and detection of complications of COVID-19 (Gallo Marin et al., 2020). Signs and symptoms are also used in the early diagnosis of COVID-19 infection and involve:1) fever more than $37.8^{\circ} \mathrm{C}, 2$ ) headache, 3 ) dry cough.4) breathless on light effort ,5) diarrhea ,6) loss of sense of taste and smell. While symptoms of severe condition during infection include:1) high respiratory rate (more than 20 breaths/minute), 2)breathing difficulty, 3) high heart rate (more than 100 beats /minute), 4) loss of appetite,5) chest tightness, 6) confusion, 7) temperature more than $\left.38^{\circ} \mathrm{C}, 8\right)$, hypoxia (Emperador \& Dittrich, 2020).

BM have been referred to a measurement variable that is based on the results of the progression of the disease (Ballman, 2015). A measurable alterations can be assessed as a sign of normal, abnormal biological processes or pharmacological reactions to treatment intervention leading to an understanding the causes of disease, methods to diagnose it, regression, progression, and the outcome of management of disease (Kinja \& Gupta, 2011). Immunoassays and Real-Time PCR (RT-PCR) are the main methods that used in the diagnosis of COVID-19, which can be performed through a variety of clinical samples, including nasal and pharyngeal swabs, sputum, feces or blood (Whetton et al., 2020). Although the role of BM in screening patients that are infected with COVID-19 has not been accurately established as compared to RT-PCR, but the alteration in its values can be used to detect the result of coronavirus test and prediction of COVID-19 patients especially when it linked to clinical feature (Mardani et al., 2020). In addition, a high costs and the limited medical resources of RT-PCR resulted in restriction to their application, therefore the appropriate and the effective approaches are urgently required in the diagnostic process as well as to evaluate the severity of disease(Peng et al., 2020). BM are divided into two main types: 1) biomarkers of disease that are utilized in diagnosis and monitoring the progression of diseases, 2) biomarkers of exposure that are utilized in risk prediction (Mayeux, 2004).

The study reviewed a correlation between the alterations in BM and the severity of COVID-19 in addition to their diagnostic role. BM that measured and used clinically in evaluation of COVID-19 were WBC count, lymphocytes, eosinophils, neutrophils, D-dimer, fibrin degradation product, interleukin-6 (IL-6), antithrombin, platelets, creatine phosphokinase, cardiac troponin and renal biomarkers (Kermali et al., 2020). 
Corona virus attacks various systems in the body, firstly through inhalation of virus-filled particles which entered into the nasopharynx and exert its effect on the pulmonary arteries by targeting ACE2 receptors and initiating a series of micro-thrombi formation leading to consequent hypoxemic damage to many systems especially the immune system, blood vessels and gastrointestinal system because of the availability of ACE2 receptors. The immune response to a viral infection lead to formation of cells such as $\mathrm{T}$ helper cells and the natural killer (NK) cells that contribute in the destruction of lymph nodes, spleen, thymus and liver (Garg et al., 2020).

\section{BM of immunity dysfunction}

The potential mechanisms of immune defect in patients infected with covid-19 is induce the depletion and promote the exhaustion of lymphocytes especially $t$ cells, however decreasing the level of $t$ cell which is inversely related with il-6, il-10 and TNFA levels (proinflammatory cytokines) is associated with an elevating in inflammatory cytokine levels (Yang et al., 2020). Lymphopenia in covid-19 patients may be occur as a result of the inhibition of cell proliferation by acidosis, recruitment of monocytes and lymphocytes from circulation into the site of infection, prevention of $t$ cell recirculation under the influence of tnf- $\alpha 2$ which stimulate the connection of these cells to the of lymphatic organs, also lymphocytopenia may be present due to activation prompted cell death of $t$ cell by the influence of cytokine il-6 (Fouladseresht et al., 2020). il-6 gene expression is typically increased in response to a variety of infections especially viral infection and also observed in the state of hypoxia, therefore the circulating levels of il-6 (pro-inflammatory cytokine) are noticed to be higher in patients with covid-19 (McElvaney et al., 2020).

Furthermore, measuring the IL-6 levels is consider a good biomarker in the prediction and evaluation the progression of COVID19 patients (Changsong Wang et al., 2020). Several studies used in analysing the immune response in COVID-19 patients and showed an enhancing in inflammatory cytokine (Luo et al., 2020; Liu Fang, et al., 2020) and decline in lymphocyte count (Wagner et al., 2020; Zhang et al., 2020; Guan et al., 2020). Eosinophils less than 100 cells $/ \mathrm{mm} 3$ is called as an eosinopenia which represent a valuable diagnostic method that help to identify patients with COVID-19 infection especially if the imaging resources has been lacking. Moreover, many studies (Djangang et al., 2020; Sun et al., 2020; Tan et al., 2020; Gong et al., 2020; Qin et al., 2020) found that eosinopenia may be occur as a result of the inflammatory state and the migration of eosinophils from the bone marrow into the peripheral tissues or decreased their production. Neutrophilia is a part of abnormal immune responses and act as a biomarkers for predicting COVID-19 disease. This is consistent with prior findings showing that patients with COVID-19 exhibiting a higher neutrophil count through the period of disease (Wang et al., 2020; Kong et al., 2020; Extracellular \& Drive, 2020; Zhao et al., 2020). Like neutrophils, WBC count are also parameter that used as an indicator of inflammatory state. Several studies found that leukocytosis are associated with cytokine storm due to virus invasion in the human body (Yuan et al., 2020; Zhao et al., 2020; He et al., 2020) (Table 1 \& 2) 
Table 1: Research articles that commonly use biochemical markers as diagnostic tool

\begin{tabular}{|c|c|c|c|c|c|}
\hline Authors & $\begin{array}{l}\text { Study } \\
\text { period }\end{array}$ & $\begin{array}{c}\text { Sample } \\
\text { size }\end{array}$ & Biomarker & $\begin{array}{c}\text { Type of } \\
\text { alteration }\end{array}$ & Comments \\
\hline $\begin{array}{c}\text { (Changzheng } \\
\text { Wang et al., } \\
\text { 2020) }\end{array}$ & $\begin{array}{c}\text { January 23- } \\
\text { February } \\
13,2020\end{array}$ & 45 & \multirow[t]{4}{*}{ WBC count } & \multirow[t]{4}{*}{ Increased } & \multirow[t]{4}{*}{$\begin{array}{l}\text { Leukocytosis may reflect a state of } \\
\text { severe inflammation in lung and other } \\
\text { organs that occur due to aggravation } \\
\text { of the Covid-19 disease by be a } \\
\text { cytokine storm }\end{array}$} \\
\hline $\begin{array}{l}\text { (Yuan et al., } \\
\text { 2020) }\end{array}$ & $\begin{array}{l}\text { February } \\
15-\text { March } \\
30,2020\end{array}$ & 117 & & & \\
\hline $\begin{array}{c}\text { ( Zhao et al., } \\
\text { 2020) }\end{array}$ & $\begin{array}{l}\text { February 3- } \\
\text { March 3, } \\
2020\end{array}$ & 619 & & & \\
\hline $\begin{array}{l}\text { (He et al., } \\
2020)\end{array}$ & $\begin{array}{c}\text { Jan 15-Mar } \\
10,2020\end{array}$ & 288 & & & \\
\hline $\begin{array}{l}\text { (Wagner et } \\
\text { al., 2020) }\end{array}$ & $\begin{array}{l}\text { January 3- } \\
\text { January 5, } \\
2020\end{array}$ & 57 & \multirow[t]{4}{*}{ Lymphocytes } & \multirow[t]{4}{*}{ Decreased } & \multirow[t]{4}{*}{$\begin{array}{l}\text { Lymphocyte count has a laboratory } \\
\text { value aiding physicians in managing } \\
\text { Covid- } 19 \text { infection and used as } \\
\text { diagnostic tool }\end{array}$} \\
\hline $\begin{array}{c}\text { ( Liu et al., } \\
2020 \text { ) }\end{array}$ & $\begin{array}{l}\text { December } \\
30 \\
2019- \\
\text { January } 15 \\
2020 \\
\end{array}$ & 78 & & & \\
\hline $\begin{array}{l}\text { ( jin Zhang et } \\
\text { al., 2020) }\end{array}$ & $\begin{array}{c}\text { January 16- } \\
\text { 3-Feb-20 }\end{array}$ & 242 & & & \\
\hline $\begin{array}{l}\text { (Guan et al., } \\
\text { 2020) }\end{array}$ & $\begin{array}{l}\text { December } \\
11,2019- \\
\text { January } 29 \\
\quad 2020\end{array}$ & 1099 & & & \\
\hline
\end{tabular}




\begin{tabular}{|c|c|c|c|c|c|}
\hline Authors & $\begin{array}{l}\text { Study } \\
\text { period }\end{array}$ & $\begin{array}{l}\text { Sample } \\
\text { size }\end{array}$ & Biomarker & $\begin{array}{l}\text { Type of } \\
\text { alteration }\end{array}$ & Comments \\
\hline $\begin{array}{l}\text { (Ndieugnou } \\
\text { Djangang et } \\
\text { al., 2020) }\end{array}$ & $\begin{array}{l}\text { March 10- } \\
31 \text { March, } \\
2020\end{array}$ & 174 & \multirow[t]{5}{*}{ Eosinophils } & \multirow[t]{5}{*}{ Decreased } & \multirow[t]{5}{*}{$\begin{array}{l}\text { sensitivity of eosinophils for the } \\
\text { detection of COVID- } 19 \text { are more than } \\
\text { lymphocytes in the term of disease } \\
\text { diagnosis, it was markedly decreased } \\
\text { in majority of peoples infected with } \\
\text { COVID-19 at their disease onset }\end{array}$} \\
\hline $\begin{array}{l}\text { (Sun et al., } \\
\text { 2020) }\end{array}$ & $\begin{array}{l}\text { January 19- } \\
\text { February } \\
20,2020\end{array}$ & 116 & & & \\
\hline $\begin{array}{l}\text { (Tan et al., } \\
\text { 2020) }\end{array}$ & $\begin{array}{l}\text { January } 30- \\
\text { February } \\
30,2020\end{array}$ & 40 & & & \\
\hline $\begin{array}{l}\text { (Gong et al., } \\
2020)\end{array}$ & $\begin{array}{c}\text { Jan 28-Mar } \\
26,2020\end{array}$ & & & & \\
\hline $\begin{array}{l}\text { (Qin et al., } \\
\text { 2020) }\end{array}$ & $\begin{array}{l}10 \text { January- } \\
12 \text { February } \\
2020\end{array}$ & 452 & & & \\
\hline $\begin{array}{c}\text { (Wang et al., } \\
2020 \text { ) }\end{array}$ & $\begin{array}{l}\text { January 23- } \\
\text { March 15, } \\
2020 .\end{array}$ & 55 & \multirow[t]{4}{*}{ Neutrophils } & \multirow[t]{4}{*}{ Increased } & \multirow[t]{4}{*}{$\begin{array}{l}\text { Excessive neutrophils act as a } \\
\text { biomarkers for predicting COVID-19 } \\
\text { disease }\end{array}$} \\
\hline $\begin{array}{l}\text { (Kong et al., } \\
2020)\end{array}$ & $\begin{array}{l}27 \text { January- } \\
9 \text { March } \\
2020\end{array}$ & 210 & & & \\
\hline $\begin{array}{l}\text { (Extracellular } \\
\text { \& Drive, 2020) }\end{array}$ & & & & & \\
\hline $\begin{array}{c}\text { ( Zhao et al., } \\
2020 \text { ) }\end{array}$ & $\begin{array}{c}\text { January } \\
\text { 13-March 4, } \\
2020\end{array}$ & 539 & & & \\
\hline
\end{tabular}




\section{BM of Coagulation abnormalities}

COVID-19 infection stimulates the immune-hemostatic response, therefore triggering an excessive inflammation, thrombotic complications and tissue damage and leading to many complications such as respiratory dysfunction, acute lung injury, many organ failure and the highest mortality rate. A wide range of laboratory tests including the coagulation parameter was reported in peoples with COVID-19 and appeared abnormalities, including D-dimer, fibrinogen degradation products, antithrombin, platelet count and prothrombin time (Fei et al., 2020). All these biochemical parameters are prognostic markers for the severity of the pathological condition for patients who have admitted to COVID-19 infection (Yao et al., 2020).

D-dimer could be an effective and helpful biomarker to improve management and treatment of Covid19 patients (Zhang et al., 2020). In addition increasing D-dimer level was related to a hazard ratio for death due to the underlying thromboembolic burden and increased mortality among those patients (Naymagon et al., 2020). Moreover, D-dimer is a reflective of high thrombotic activity and may not only be a biomarker of prothrombotic state and a hypercoagulability but may contribute in pathogenesis of acute pulmonary dysfunction (Berger et al., 2020). Elevated fibrin degradation products has been reported in several studies leading to serious condition caused by disseminated intravascular coagulation, which requires continuous attention and prompt intervention (Terpos et al., 2020; Zheng et al., 2020). While the reduction in antithrombin levels in patients with COVID-19 are also appear to have an important role in patient prognosis through both arterial and venous thrombotic complications (Liao et al., 2020; Christensen et al., 2020). Like antithrombin, a low platelet count is accompanying by fivefold increased risk of disease and mortality in COVID-19 patients and therefore should used as prognostic indicator of worsening disease during hospitalization (Lippi et al., 2020). Many studies revealed a thrombocytopenia in groups of patients with severe COVID-19 and associated with increasing the mortality many times higher than in patients without thrombocytopenia ( Liu et al., 2020; Zhao et al., 2020).

\section{BM of Cardiac complications}

COVID-19 usually presents as viral pneumonia that may resulting in acute respiratory distress syndrome and it has a signifcant effect on the cardiovascular system through severe systemic inflammatory response, hypoxia, direct myocardial damage, lung injury and the major cardiac complications are myocardial infarction, acute myocarditis, arrhythmia and abnormal clotting (Bandyopadhyay et al., 2020). Creatine phosphokinase and cardiac troponin are a prognostic tool that utilized as a circulating cardiac injury marker, and a patients with higher levels of these biomarkers are associated with increased severity of COVID-19 death (Qin et al., 2020; Masetti et al., 2020; Izquierdo et al., 2020; Salvatici et al., 2020; Shah et al., 2020). (Table 2) 
Table 2: Study details of research articles that commonly used biochemical markers as prognostic tools

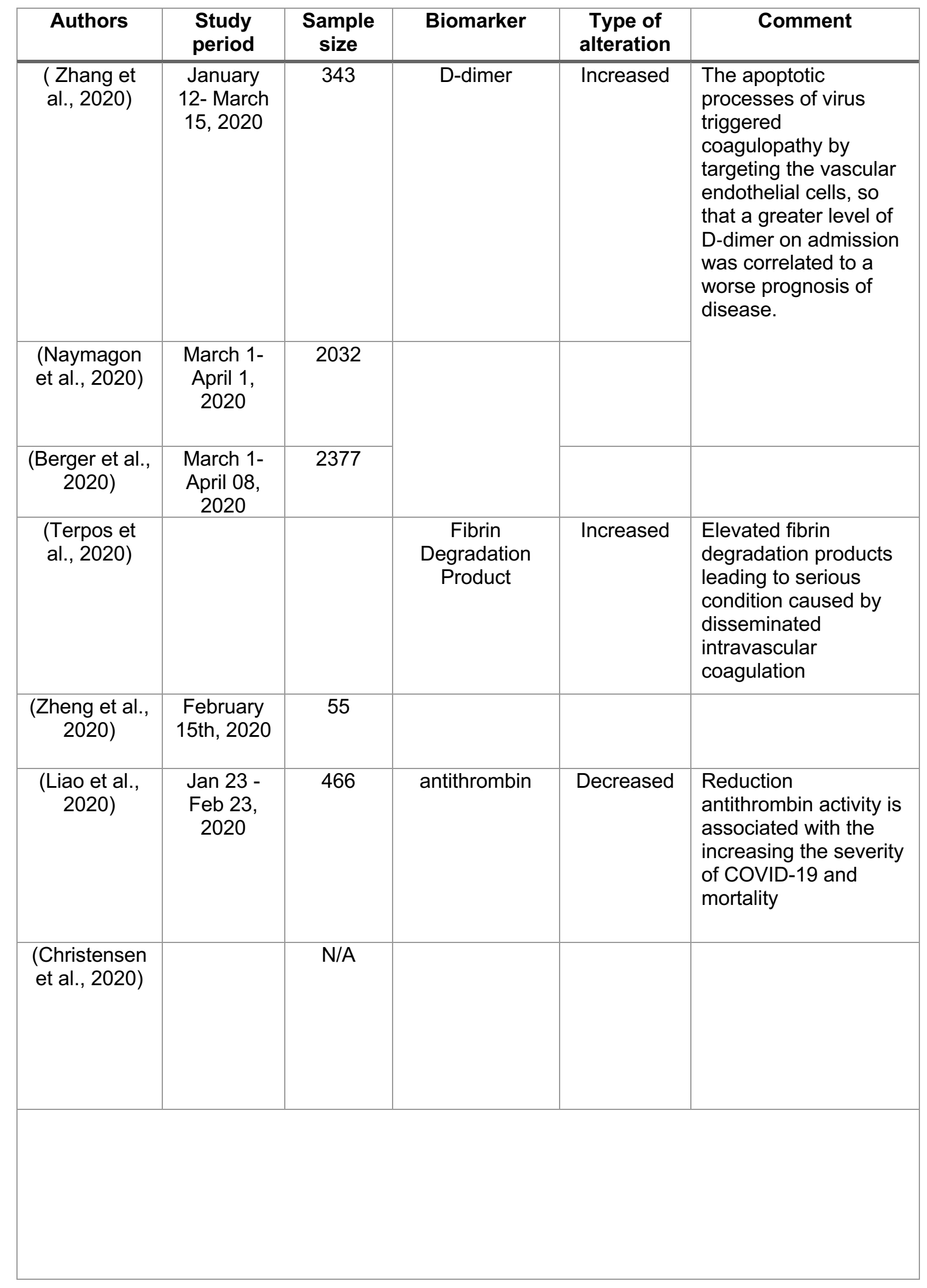




\begin{tabular}{|c|c|c|c|c|c|}
\hline Authors & $\begin{array}{l}\text { Study } \\
\text { period }\end{array}$ & $\begin{array}{l}\text { Sample } \\
\text { size }\end{array}$ & Biomarker & $\begin{array}{c}\text { Type of } \\
\text { alteration }\end{array}$ & Comment \\
\hline $\begin{array}{l}\text { ( Liu et al., } \\
\text { 2020) }\end{array}$ & $\begin{array}{c}\text { January } 2 \\
\text { March 1, } \\
2020 .\end{array}$ & 383 & Platelets & Decreased & $\begin{array}{l}\text { Platelet count is readily } \\
\text { available } \\
\text { biomarker,could } \\
\text { distinguish COVID-19 } \\
\text { patients with severe } \\
\text { disease. }\end{array}$ \\
\hline $\begin{array}{c}\text { ( Zhao et al., } \\
2020)\end{array}$ & $\begin{array}{c}\text { January } 7- \\
\text { February } \\
28,2020\end{array}$ & 1066 & & & \\
\hline $\begin{array}{l}\text { (Qin et al., } \\
\text { 2020) }\end{array}$ & $\begin{array}{c}\text { December } \\
31,2019- \\
\text { March 4, } \\
2020\end{array}$ & 3219 & $\begin{array}{c}\text { creatine } \\
\text { phosphokinase }\end{array}$ & Increased & $\begin{array}{l}\text { creatine } \\
\text { phosphokinase is a } \\
\text { prognostic tool using } \\
\text { as a circulating cardiac } \\
\text { injury marker }\end{array}$ \\
\hline $\begin{array}{l}\text { (Masetti et } \\
\text { al., 2020) }\end{array}$ & $\begin{array}{c}28 \\
\text { February- } \\
10 \text { April } \\
2020\end{array}$ & 229 & & & \\
\hline $\begin{array}{l}\text { (Izquierdo et } \\
\text { al., 2020) }\end{array}$ & $\begin{array}{c}\text { February } \\
27 \text {-April } 7 \\
2020\end{array}$ & 872 & & & \\
\hline $\begin{array}{l}\text { (Salvatici et } \\
\text { al., 2020) }\end{array}$ & $\begin{array}{l}1 \text { March- } \\
14 \text { April } \\
2020\end{array}$ & 523 & cardiac troponin & Increased & $\begin{array}{l}\text { Cardiac troponin is a } \\
\text { useful biomarker of } \\
\text { myocardial injury and } \\
\text { the elevation in its } \\
\text { concentration } \\
\text { associated with } \\
\text { increased mortality } \\
\text { rate in patients with } \\
\text { worse clinical } \\
\text { outcomes in COVID-19 } \\
\text { infection. }\end{array}$ \\
\hline $\begin{array}{c}\text { (Shah et al., } \\
2020)\end{array}$ & $\begin{array}{l}\text { March 2- } \\
\text { June 7, } \\
2020\end{array}$ & 309 & & & \\
\hline $\begin{array}{l}\text { ( Cheng et } \\
\text { al., 2020) }\end{array}$ & $\begin{array}{c}8 \\
\text { February- } \\
11 \text { March } \\
2020\end{array}$ & 305 & $\begin{array}{l}\text { Blood urea } \\
\text { nitrogen }\end{array}$ & Increased & $\begin{array}{l}\text { Blood urea nitrogen is } \\
\text { consider an important } \\
\text { marker for predicting, } \\
\text { estimation of renal } \\
\text { function and represent } \\
\text { a valuable prognostic } \\
\text { factor of COVID-19 } \\
\text { severity }\end{array}$ \\
\hline $\begin{array}{l}\text { (Gao et al., } \\
2020)\end{array}$ & $\begin{array}{l}\text { January } \\
23- \\
\text { February } \\
29,2020\end{array}$ & 210 & & & \\
\hline
\end{tabular}




\begin{tabular}{|c|c|c|c|c|c|}
\hline $\begin{array}{l}\text { ( Cheng et } \\
\text { al., 2020) }\end{array}$ & $\begin{array}{c}\text { January } \\
28- \\
\text { February } \\
112020 \text {, }\end{array}$ & 701 & Creatinine & Increased & $\begin{array}{l}\text { Creatinine } \\
\text { measurements is a } \\
\text { very useful prognostic } \\
\text { tool in the early } \\
\text { detection of kidney } \\
\text { injury }\end{array}$ \\
\hline $\begin{array}{l}\text { (Pei et al., } \\
\text { 2020) }\end{array}$ & $\begin{array}{c}\text { January } \\
28- \\
\text { February } \\
9,2020\end{array}$ & 333 & & & \\
\hline $\begin{array}{l}\text { (Nimkar et } \\
\text { al., 2020) }\end{array}$ & $\begin{array}{c}\text { March 10- } \\
\text { May 13, } \\
2020\end{array}$ & 370 & & & \\
\hline $\begin{array}{l}\text { ( Liu et al., } \\
2020 \text { ) }\end{array}$ & $\begin{array}{c}\text { January } \\
21- \\
\text { February } \\
16,2020\end{array}$ & 69 & Interleukin-6 & Increased & $\begin{array}{l}\text { High level of IL6 } \\
\text { mayreflect a state of } \\
\text { acute inflammatory } \\
\text { cytokine storm } \\
\text { indicating disease } \\
\text { progression }\end{array}$ \\
\hline $\begin{array}{l}\text { ( Liu Tao et } \\
\text { al., 2020) }\end{array}$ & $\begin{array}{c}\text { January } \\
21 \text { - } \\
\text { February } \\
16,2020\end{array}$ & 80 & & & \\
\hline $\begin{array}{l}\text { ( Liu Fang, et } \\
\text { al., 2020) }\end{array}$ & $\begin{array}{c}\text { January } \\
\text { 18- March } \\
12,2020\end{array}$ & 140 & & & \\
\hline $\begin{array}{l}\text { (Luo et al., } \\
2020)\end{array}$ & $\begin{array}{c}\text { January } \\
27-5 \\
\text { March } \\
2020\end{array}$ & 15 & & & \\
\hline
\end{tabular}

\section{BM of Renal failure}

Recent studies show that renal injury is commonly occur in coronavirus patients because of a highly presented ACE2 receptors in the renal cells which making them targeted and infected by the coronavirus (Valizadeh et al., 2020). However, The possible mechanisms for the kidney manifestations of COVID-19 are:1) renal dysfunction due to viral replication, 2) systemic inflammatory response for the cytokine storm, 3) disturbance in renin angiotensin aldosterone system homeostasis (Kunutsor \& Laukkanen, 2020). Increased level of blood urea nitrogen is a risk factors for poor prognosis of coronavirus especially when it infected the elderly patients with comorbidities (Cheng et al., 2020; Gao et al., 2020). The occurrence of acute renal injury as a one complication of COVID-19 infection is a partly detected through measuring creatinine levels, because of the diagnosis of renal injury is generally depend on the acute changes in the levels of creatinine in the serum which has a substantial effect on detection rate ( Cheng et al., 2020; Pei et al., 2020; Nimkar et al., 2020). 


\section{Conclusion}

In conclusion, we found that there are many biochemical markers that play an important roles in predicting of COVID-19 infection with a clear evidence of how their levels may alter according to the severity of COVID-19. This may be ultimately helped the clinicians in their clinical practice to guide management and to determine the necessity for admission to ICU in order to decrease the mortality rates.

\section{Recommendation}

To illustrate that a biomarkers are predictive of management and treatment benefit, the study requires biomarkers status on all patients preferably in the context of a randomized study and to determine whether a biomarkers are purely prognostic, it requires to be demonstrated that there is a significant correlation between the biomarkers and outcome.

\section{Conflicts of Interest:}

The authors declare no conflicts of interest.

\section{References}

- Ballman, K. V. (2015). Biomarker: Predictive or prognostic? Journal of Clinical Oncology, 33(33), 3968-3971. https://doi.org/10.1200/JCO.2015.63.3651

- Bandyopadhyay, D., Akhtar, T., Hajra, A., Gupta, M., \& Das, A. (2020). COVID - 19 Pandemic : Cardiovascular Complications and Future Implications. American Journal of Cardiovascular Drugs, 20(4), 311-324. https://doi.org/10.1007/s40256-020-00420-2

- Bano, F., Tahir, A., \& Ghani, M. (2020). Prognostic and Predictive Role of Selected Biochemical Markers in COVID-19. 36, 213-219.

- Berger, J. S., Kunichoff, D., Adhikari, S., Ahuja, T., Amoroso, N., Aphinyanaphongs, Y., Cao, M., Goldenberg, R., Hindenburg, A., Horowitz, J., Parnia, S., Petrilli, C., Reynolds, H., Simon, E., Slater, J., Yaghi, S., Yuriditsky, E., Hochman, J., \& Horwitz, L. I. (2020). Prevalence and Outcomes of D-Dimer Elevation in Hospitalized Patients with COVID-19. Arteriosclerosis, Thrombosis, and Vascular Biology, October, 2539-2547. https://doi.org/10.1161/ATVBAHA.120.314872

- Cheng, A., Hu, L., Wang, Y., Huang, L., Zhao, L., Zhang, C., Liu, X., Xu, R., Liu, F., Li, J., Ye, D., Wang, T., Lv, Y., \& Liu, Q. (2020). Diagnostic performance of initial blood urea nitrogen combined with D-dimer levels for predicting in-hospital mortality in COVID-19 patients. International Journal of Antimicrobial Agents, 56(3). https://doi.org/10.1016/j.ijantimicag.2020.106110

- $\quad$ Cheng, Y., Luo, R., Wang, K., Zhang, M., Wang, Z., Dong, L., Li, J., Yao, Y., Ge, S., \& Xu, G. (2020). Kidney disease is associated with in-hospital death of patients with COVID-19. Kidney International, 97(5), 829-838. https://doi.org/10.1016/j.kint.2020.03.005

- Christensen, B., Favaloro, E. J., Lippi, G., \& Van Cott, E. M. (2020). Hematology Laboratory Abnormalities in Patients with Coronavirus Disease 2019 (COVID-19). Seminars in Thrombosis and Hemostasis, 46(7), 845-849. https://doi.org/10.1055/s-0040-1715458

- Emperador, D., \& Dittrich, S. (2020). Deeks JJ, Dinnes J, Takwoingi Y, Davenport C, Leeflang MMG, Spijker R, Hoo L, Van den Bruel A, Emperador D, Dittrich S. https://doi.org/10.1002/14651858.CD013596.www.cochranelibrary.com

- Extracellular, N., \& Drive, T. (2020). Necroinflammation in COVID-19. 1-8.

- Fei, Y., Tang, N., Liu, H., \& Cao, W. (2020). Coagulation dysfunction: A hallmark in COVID-19. Archives of Pathology and Laboratory Medicine, 144(10), 1223-1229. https://doi.org/10.5858/arpa.2020-0324-SA 
- Fouladseresht, H., Doroudchi, M., Rokhtabnak, N., Abdolrahimzadehfard, H., Roudgari, A., Sabetian, G., \& Paydar, S. (2020). Predictive monitoring and therapeutic immune biomarkers in the management of clinical complications of COVID-19. Cytokine and Growth Factor Reviews, October. https://doi.org/10.1016/j.cytogfr.2020.10.002

- Gallo Marin, B., Aghagoli, G., Lavine, K., Yang, L., Siff, E. J., Chiang, S. S., Salazar-Mather, T. P., Dumenco, L., Savaria, M. C., Aung, S. N., Flanigan, T., \& Michelow, I. C. (2020). Predictors of COVID-19 severity: A literature review. Reviews in Medical Virology, May. https://doi.org/10.1002/rmv.2146

- Gao, S., Jiang, F., Jin, W., Shi, Y., Yang, L., Xia, Y., Jia, L., Wang, B., Lin, H., Cai, Y., Xia, Z., \& Peng, J. (2020). Gao et al - Risk factors influencing the prognosis of elderly patients infected with COVID-19. 12(13), 12504-12516.

- Garg, S., Garg, M., Prabhakar, N., Malhotra, P., \& Agarwal, R. (2020). Unraveling the mystery of Covid-19 cytokine storm: From skin to organ systems. Dermatologic Therapy, June. https://doi.org/10.1111/dth.13859

- Gong, Y., Zhang, X., Wu, Z., Cheng, Y., Zhang, B., Zhou, X., Gao, L., Yang, Q., Zhao, H., Feng, J., Cui, L., Liao, L., Du, Y., Su, H., \& Song, Q. (2020). The Dynamic Changes of Eosinophils and Its Potential Predictive Value in Patients with COVID-19. SSRN Electronic Journal, 302. https://doi.org/10.2139/ssrn.3576839

- Guan, W., Ni, Z., Hu, Y., Liang, W., Ou, C., He, J., Liu, L., Shan, H., Lei, C., Hui, D. S. C., Du, B., Li, L., Zeng, G., Yuen, K.-Y., Chen, R., Tang, C., Wang, T., Chen, P., Xiang, J., ... Zhong, N. (2020). Clinical Characteristics of Coronavirus Disease 2019 in China. New England Journal of Medicine, 382(18), 1708-1720. https://doi.org/10.1056/nejmoa2002032

- He, F., Luo, Q., Lei, M., Fan, L., Shao, X., Huang, G., Zeng, J., Zhao, Z., Qin, S., Yang, Z., Yu, N., Yang, L., \& Cao, J. (2020). Risk factors for severe cases of COVID-19: A retrospective cohort study. Aging, 12(15), 15730-15740. https://doi.org/10.18632/AGING.103803

- Henry, B. M., De Oliveira, M. H. S., Benoit, S., Plebani, M., \& Lippi, G. (2020). Hematologic, biochemical and immune biomarker abnormalities associated with severe illness and mortality in coronavirus disease 2019 (COVID-19): A meta-analysis. Clinical Chemistry and Laboratory Medicine, 58(7), 1021-1028. https://doi.org/10.1515/cclm-2020-0369

- Izquierdo, A., Subirana, I., Farre, N., Calvo-ferna, A., Garcı, M., Valdivielso, S., Cabero, P., Soler, C., Dura, X., Rodrı, C., Llagostera, M., Mojo, D., Garcı, C., Sa, A., Tevar, C., Sole, E., \& Vaquerizo, B. (2020). Markers of myocardial injury in the prediction of short-term COVID-19 prognosis. x. https://doi.org/10.1016/j.rec.2020.09.011

- Kermali, M., Khalsa, R. K., Pillai, K., Ismail, Z., \& Harky, A. (2020). The role of biomarkers in diagnosis of COVID-19 - A systematic review. Life Sciences, 254(May), 117788. https://doi.org/10.1016/j.lfs.2020.117788

- Kinja, K., \& Gupta, N. (2011). A review on "Biomarkers" as diagnostic tool. International Journal of Pharmaceutical Sciences Review and Research, 7(1), 54-58.

- Kong, M., Zhang, H., Cao, X., Mao, X., \& Lu, Z. (2020). Higher level of Neutrophil-toLymphocyte is associated with severe COVID-19. Epidemiology and Infection, 1-6. https://doi.org/10.1017/S0950268820001557

- Kunutsor, S. K., \& Laukkanen, J. A. (2020). Renal complications in COVID-19: a systematic review and meta-analysis. Annals of Medicine, 52(7), 1-9. https://doi.org/10.1080/07853890.2020.1790643

- Liao, D., Zhou, F., Luo, L., Xu, M., Wang, H., Xia, J., Gao, Y., Cai, L., Wang, Z., Yin, P., Wang, Y., Tang, L., Deng, J., Mei, H., \& Hu, Y. (2020). Haematological characteristics and risk factors in the classification and prognosis evaluation of COVID-19: a retrospective cohort study. The Lancet Haematology, 7(9), e671-e678. https://doi.org/10.1016/S2352-3026(20)30217-9

- Lippi, G., Plebani, M., \& Michael, B. (2020). Clinica Chimica Acta Thrombocytopenia is associated with severe coronavirus disease 2019 ( COVID-19) infections: A meta -analysis. Clinica Chimica Acta, 506(March), 145-148. https://doi.org/10.1016/j.cca.2020.03.022

- Liu, F., Li, L., Xu, M. Da, Wu, J., Luo, D., Zhu, Y. S., Li, B. X., Song, X. Y., \& Zhou, X. (2020). Prognostic value of interleukin-6, C-reactive protein, and procalcitonin in patients with COVID19. Journal of Clinical Virology, 127(April), 104370. https://doi.org/10.1016/j.jcv.2020.104370

- Liu, T., Zhang, J., Yang, Y., Ma, H., Li, Z., Zhang, J., Cheng, J., Zhang, X., Zhao, Y., Xia, Z., Zhang, L., Wu, G., \& Yi, J. (2020). The role of interleukin-6 in monitoring severe case of coronavirus disease 2019. EMBO Molecular Medicine, 12(7), 1-12. https://doi.org/10.15252/emmm.202012421 
- Liu, T., Zhang, J., Yang, Y., Zhang, L., Ma, H., Li, Z., Zhang, J., Cheng, J., Zhang, X., Wu, G., \& Yi, J. (2020). The Potential Role of IL-6 in Monitoring Coronavirus Disease 2019. SSRN Electronic Journal. https://doi.org/10.2139/ssrn.3548761

- Liu, W., Tao, Z. W., Wang, L., Yuan, M. L., Liu, K., Zhou, L., Wei, S., Deng, Y., Liu, J., Liu, H. G., Yang, M., \& Hu, Y. (2020). Analysis of factors associated with disease outcomes in hospitalized patients with 2019 novel coronavirus disease. Chinese Medical Journal, 133(9), 1032-1038. https://doi.org/10.1097/CM9.0000000000000775

- $\quad$ Liu, Y., Sun, W., Guo, Y., Chen, L., Zhang, L., Zhao, S., Liu, Y., Sun, W., Guo, Y., Chen, L., Zhang, L., Zhao, S., Long, D., \& Yu, L. (2020). Association between platelet parameters and mortality in coronavirus disease 2019: Retrospective cohort study Association between platelet parameters and mortality in coronavirus disease 2019: Retrospective cohort study. https://doi.org/10.1080/09537104.2020.1754383

- Luo, P., Liu, Y., Quu, L., Liu, X., Liu, D., \& Li, J. (2020). Tocilizumab treatment in COVID-19: A single center experience. Journal of Medical Virology, 92(7), 814-818. https://doi.org/10.1002/jmv.25801

- Mardani, R., Vasmehjani, A. A., Zali, F., Gholami, A., \& Mousavi, S. D. (2020). Laboratory Parameters in Detection of COVID-19 Patients with Positive RT-PCR ; a Diagnostic Accuracy Study. 8(1), 4-8.

- Masetti, C., Generali, E., Colapietro, F., Voza, A., Cecconi, M., Messina, A., Omodei, P., Angelini, C., Ciccarelli, M., Badalamenti, S., Canonica, G. W., \& Lleo, A. (2020). High mortality in COVID-19 patients with mild respiratory disease. June, 1-6. https://doi.org/10.1111/eci.13314

- Mayeux, R. (2004). Biomarkers: Potential Uses and Limitations. NeuroRx, 1(2), 182-188. https://doi.org/10.1602/neurorx.1.2.182

- McElvaney, O. J., Hobbs, B. D., Qiao, D., McElvaney, O. F., Moll, M., McEvoy, N. L., Clarke, J., O'Connor, E., Walsh, S., Cho, M. H., Curley, G. F., \& McElvaney, N. G. (2020). A linear prognostic score based on the ratio of interleukin- 6 to interleukin-10 predicts outcomes in COVID-19. EBioMedicine, 61. https://doi.org/10.1016/j.ebiom.2020.103026

- Naymagon, L., Zubizarreta, N., Feld, J., van Gerwen, M., Alsen, M., Thibaud, S., Kessler, A., Venugopal, S., Makki, I., Qin, Q., Dharmapuri, S., Jun, T., Bhalla, S., Berwick, S., Christian, K., Mascarenhas, J., Dembitzer, F., Moshier, E., \& Tremblay, D. (2020). Admission D-dimer levels, D-dimer trends, and outcomes in COVID-19. Thrombosis Research, 196(June), 99-105. https://doi.org/10.1016/j.thromres.2020.08.032

- Ndieugnou Djangang, N., Peluso, L., Talamonti, M., Izzi, A., Gevenois, P. A., Garufi, A., Goffard, J.-C., Henrard, S., Severgnini, P., Vincent, J.-L., Creteur, J., \& Taccone, F. S. (2020). Eosinopenia in COVID-19 Patients: A Retrospective Analysis. Microorganisms, 8(12), 1-12. https://doi.org/10.3390/microorganisms8121929

- Nimkar, A., Naaraayan, A., Hasan, A., Pant, S., Durdevic, M., Suarez, C. N., Elenius, H., Hambardzumyan, A., Lakshmi, K., Mandel, M., \& Jesmajian, S. (2020). Incidence and Risk Factors for Acute Kidney Injury and its effect on Mortality in Patients Hospitalized from Covid19. Mayo Clinic Proceedings: Innovations, Quality \& Outcomes, 4(6), 687-695. https://doi.org/10.1016/j.mayocpiqo.2020.07.003

- Pei, G., Zhang, Z., Peng, J., Liu, L., Zhang, C., Yu, C., Ma, Z., Huang, Y., Liu, W., Yao, Y., Zeng, R., \& Xu, G. (2020). Renal involvement and early prognosis in patients with COVID-19 pneumonia. Journal of the American Society of Nephrology, 31(6), 1157-1165. https://doi.org/10.1681/ASN.2020030276

- Peng, J., Qi, D., Yuan, G., Deng, X., Mei, Y., Feng, L., \& Wang, D. (2020). Diagnostic value of peripheral hematologic markers for coronavirus disease 2019 (COVID-19): A multicenter, cross-sectional study. Journal of Clinical Laboratory Analysis, 34(10), 1-10. https://doi.org/10.1002/jcla.23475

- Qin, C., Zhou, L., Hu, Z., Zhang, S., Yang, S., Tao, Y., Xie, C., Ma, K., Shang, K., Wang, W., \& Tian, D. S. (2020). Dysregulation of immune response in patients with coronavirus 2019 (COVID-19) in Wuhan, China. Clinical Infectious Diseases, 71(15), 762-768. https://doi.org/10.1093/cid/ciaa248

- Qin, J., Cheng, X., Zhou, F., Lei, F., Akolkar, G., Cai, J., Zhang, X., Blet, A., Xie, J., Zhang, P., Liu, Y., Huang, Z., Zhao, L., Lin, L., Xia, M., Chen, M., Song, X., Bai, L., ... Li, H. (2020). Redefining Cardiac Biomarkers in Predicting Mortality of. 1104-1112. https://doi.org/10.1161/HYPERTENSIONAHA.120.15528 
- Salvatici, M., Barbieri, B., Cioffi, S. M. G., Morenghi, E., Leone, F. P., Maura, F., Moriello, G., \& Sandri, M. T. (2020). Association between cardiac troponin I and mortality in patients with COVID-19. Biomarkers, 25(8), 635-641. https://doi.org/10.1080/1354750X.2020.1831609

- Shah, P., Doshi, R., Chenna, A., Owens, R., Cobb, A., Ivey, H., Newton, S., \& Mccarley, K. (2020). Prognostic Value of Elevated Cardiac Troponin I in Hospitalized Covid-19 Patients. American Journal of Cardiology, 135, 150-153. https://doi.org/10.1016/j.amjcard.2020.08.041

- Sun, S., Cai, X., Wang, H., He, G., Lin, Y., Lu, B., Chen, C., Pan, Y., \& Hu, X. (2020). Abnormalities of peripheral blood system in patients with COVID-19 in Wenzhou, China. Clinica Chimica Acta, 507(April), 174-180. https://doi.org/10.1016/j.cca.2020.04.024

- Tan, Y., Zhou, J., Zhou, Q., Hu, L., \& Long, Y. (2020). Role of eosinophils in the diagnosis and prognostic evaluation of COVID-19. Journal of Medical Virology, April. https://doi.org/10.1002/jmv.26506

- Terpos, E., Ntanasis-Stathopoulos, I., Elalamy, I., Kastritis, E., Sergentanis, T. N., Politou, M., Psaltopoulou, T., Gerotziafas, G., \& Dimopoulos, M. A. (2020). Hematological findings and complications of COVID-19. American Journal of Hematology, 95(7), 834-847. https://doi.org/10.1002/ajh.25829

- Valizadeh, R., Baradaran, A., Mirzazadeh, A., \& Bhaskar, L. V. K. S. (2020). Coronavirusnephropathy; renal involvement in COVID-19. Journal of Renal Injury Prevention, 9(2), 3-4. https://doi.org/10.34172/jrip.2020.18

- Wagner, J., Dupont, A., Larson, S., Cash, B., \& Farooq, A. (2020). Absolute lymphocyte count is a prognostic marker in Covid-19: A retrospective cohort review. June, 761-765. https://doi.org/10.1111/ijlh.13288

- Wang, Changsong, Fei, D., Li, X., Zhao, M., \& Yu, K. (2020). IL-6 may be a good biomarker for earlier detection of COVID-19 progression. Intensive Care Medicine, 46(7), 1475-1476. https://doi.org/10.1007/s00134-020-06065-8

- Wang, Changzheng, Deng, R., Gou, L., Fu, Z., Zhang, X., Shao, F., Wang, G., Fu, W., Xiao, J., Ding, X., Li, T., Xiao, X., \& Li, C. (2020). Preliminary study to identify severe from moderate cases of COVID-19 using combined hematology parameters. Annals of Translational Medicine, 8(9), 593-593. https://doi.org/10.21037/atm-20-3391

- Wang, J., Li, Q., Yin, Y., Zhang, Y., Cao, Y., Lin, X., Huang, L., Hoffmann, D., Lu, M., \& Qiu, Y. (2020). Excessive Neutrophils and Neutrophil Extracellular Traps in COVID-19. Frontiers in Immunology, 11(August), 1-13. https://doi.org/10.3389/fimmu.2020.02063

- Whetton, A. D., Preston, G. W., Abubeker, S., \& Geifman, N. (2020). Proteomics and Informatics for Understanding Phases and Identifying Biomarkers in COVID-19 Disease. https://doi.org/10.1021/acs.jproteome.0c00326

- Yang, L., Liu, S., Liu, J., Zhang, Z., Wan, X., Huang, B., Chen, Y., \& Zhang, Y. (2020). COVID19: immunopathogenesis and Immunotherapeutics. Signal Transduction and Targeted Therapy, 5(1), 1-8. https://doi.org/10.1038/s41392-020-00243-2

- Yao, Y., Cao, J., Wang, Q., Shi, Q., Liu, K., Luo, Z., Chen, X., Chen, S., Yu, K., Huang, Z., \& $\mathrm{Hu}, \mathrm{B} .(2020)$. D-dimer as a biomarker for disease severity and mortality in COVID-19 patients: A case control study. Journal of Intensive Care, 8(1), 1-11. https://doi.org/10.1186/s40560-02000466-z

- Yuan, X., Huang, W., Ye, B., Chen, C., Huang, R., Wu, F., Wei, Q., Zhang, W., \& Hu, J. (2020). Changes of hematological and immunological parameters in COVID-19 patients. International Journal of Hematology, 112(4), 553-559. https://doi.org/10.1007/s12185-020-02930-w

- Zhang, J. jin, Dong, X., Cao, Y. yuan, Yuan, Y. dong, Yang, Y. bin, Yan, Y. qin, Akdis, C. A., \& Gao, Y. dong. (2020). Clinical characteristics of 140 patients infected with SARS-CoV-2 in Wuhan, China. Allergy: European Journal of Allergy and Clinical Immunology, 75(7), 17301741. https://doi.org/10.1111/all.14238

- Zhang, L., Yan, X., Fan, Q., Liu, H., Liu, X., Liu, Z., \& Zhang, Z. (2020). D-dimer levels on admission to predict in-hospital mortality in patients with Covid-19. Journal of Thrombosis and Haemostasis, 18(6), 1324-1329. https://doi.org/10.1111/jth.14859

- Zhao, K., Li, R., Wu, X., Zhao, Y., Wang, T., Zheng, Z., Zeng, S., Ding, X., \& Nie, H. (2020). Clinical features in 52 patients with COVID-19 who have increased leukocyte count: a retrospective analysis. European Journal of Clinical Microbiology and Infectious Diseases, 39(12), 2279-2287. https://doi.org/10.1007/s10096-020-03976-8 
- Zhao, X., Wang, K., Zuo, P., Liu, Y., Zhang, M., Xie, S., Zhang, H., Chen, X., \& Liu, C. (2020). Early decrease in blood platelet count is associated with poor prognosis in COVID-19 patientsindications for predictive, preventive, and personalized medical approach. EPMA Journal, 11(2), 139-145. https://doi.org/10.1007/s13167-020-00208-Z

- Zhao, Y., Nie, H. X., Hu, K., Wu, X. J., Zhang, Y. T., Wang, M. M., Wang, T., Zheng, Z. S., Li, X. C., \& Zeng, S. L. (2020). Abnormal immunity of non-survivors with COVID-19: Predictors for mortality. Infectious Diseases of Poverty, 9(1), 1-10. https://doi.org/10.1186/s40249-02000723-1

- Zheng, C., Wang, J., Guo, H., Lu, Z., Ma, Y., Zhu, Y., Xia, D., Wang, Y., He, H., \& Zhou, J. (2020). International Journal of Infectious Diseases Risk-adapted Treatment Strategy For COVID-19 Patients Anhui Medical team members of National aid to prevent and treat novel coronavirus pneumonia in Wuhan. International Journal of Infectious Diseases, 94, 74-77. https://doi.org/10.1016/j.ijid.2020.03.047 